Article

\title{
Rapid synthesis of nitrogen-doped graphene by microwave heating for oxygen reduction reactions in alkaline electrolyte
}

\author{
Zhongwei Wang a,b, Bo Li a,b, Yuchen Xin a,b, Jianguo Liu a,b,*, Yingfang Yao a,b, Zhigang Zou a,b,\# \\ a Eco-materials and Renewable Energy Research Center, Department of Materials Science and Engineering, National Laboratory of Solid State Micro- \\ structures, Nanjing University, Nanjing 210093, Jiangsu, China \\ ${ }^{\mathrm{b}}$ Kunshan Innovation Institute of Nanjing University, Suzhou 215347, Jiangsu, China
}

\section{A R T I C L E I N F O}

Article history:

Received 28 November 2013

Accepted 27 December 2013

Published 20 April 2014

\section{Keywords:}

Fuel cell

Oxygen reduction reaction

Onset potential

Nitrogen doped graphene

Microwave heating

\section{A B S T R A C T}

Nitrogen-doped graphene (NG) with a nitrogen content from $4.05 \mathrm{wt} \%$ to $5.47 \mathrm{wt} \%$ was rapidly prepared via microwave heating of graphene under $\mathrm{NH}_{3}$ flow. The as-synthesized $\mathrm{NG}$ samples were then used as electrocatalysts in the oxygen reduction reaction (ORR) in alkaline solution. The NG samples showed excellent ORR catalytic activity with an onset potential of $0.17 \mathrm{~V}$, which is comparable to that of commercial $\mathrm{Pt} / \mathrm{C}$ electrocatalyst $(0.21 \mathrm{~V})$. The structure, composition, and nitrogen species of the NG samples were examined by transmission electron microscopy, Raman spectroscopy, elemental analysis and X-ray photoelectron spectroscopy. The onset potential increases with the content of graphite nitrogen in the NG samples, indicating that graphite nitrogen might be the main factor controlling the performance of the NG samples in the ORR. The results showed that NG prepared by rapid microwave heating is a promising ORR catalyst for fuel cells.

(C) 2014, Dalian Institute of Chemical Physics, Chinese Academy of Sciences. Published by Elsevier B.V. All rights reserved.

\section{Introduction}

The progress of fuel cells has triggered a recent upsurge of the development of efficient electrocatalysts for the oxygen reduction reaction (ORR) [1]. Such electrocatalysts are generally carbon-supported Pt or Pt-based alloy nanoparticles [2]. However, critical challenges, such as high cost and scarcity [3], have precluded the large-scale commercial application of proton exchange membrane fuel cells.

Recent efforts to replace Pt have led to the development of various non-precious electrocatalysts for the ORR [4,5], in which $\mathrm{N}$-doped carbon materials, including vertically aligned carbon nanotubes [6], ordered mesoporous graphitic carbon [7], and graphene $[8,9]$, have been widely investigated. However, the methods used to dope carbon materials with $\mathrm{N}$, such as chemical vapor deposition [10], nitrogen plasma treatment [11], and thermal annealing [4], are generally time-consuming, resulting in a low production efficiency. A highly efficient, low-cost doping method needs to be developed.

Herein, we use graphene prepared by Hummers' method [12] to fabricate N-doped graphene (NG) by microwave heating in an ammonia environment. Within just tens of seconds, NG samples with a nitrogen content ranging from $4.05 \mathrm{wt} \%$ to 5.47 wt $\%$ are obtained. The performance of the NG samples in the

\footnotetext{
* Corresponding author. Tel: +86-25-83621219; E-mail: jianguoliu@nju.edu.cn

\# Corresponding author. Tel: +86-25-83686630; E-mail: zgzou@nju.edu.cn

This work was supported by the National Natural Foundation of China (21176111), the National Basic Research Program (973 Program, 2013CB632404), the National High Technology Research and Development Program of China (863 Program, 2011AA11A271), and A Project Funded by the Priority Academic Program Development of Jiangsu Higher Education Institutions.

DOI: 10.1016/S1872-2067(14)60016-4 | http://www.sciencedirect.com/science/journal/18722067 | Chin. J. Catal., Vol. 35, No. 4, April 2014
} 
ORR in alkaline solution is compared with that of non-doped graphene and commercial Pt/C catalyst. The results imply that the developed $\mathrm{N}$-doping method could be an efficient, low-cost route to prepare NG, which may contribute to the commercialization of fuel cells.

\section{Experimental}

\subsection{Preparation of catalysts}

Graphite oxide (GO) was obtained from graphite powder using a modified Hummers' method [12], which involved three steps: pre-oxidation of natural graphite with concentrated $\mathrm{H}_{2} \mathrm{SO}_{4}$ and $\mathrm{KMnO}_{4}$, re-oxidation with $\mathrm{H}_{2} \mathrm{O}_{2}$, and exfoliation by sonication. Graphene was prepared by expanding GO by microwave heating for $60 \mathrm{~s}$ under $\mathrm{N}_{2}$ flow $(200 \mathrm{~mL} / \mathrm{min})$, and then NG was synthesized via microwave heating for different periods $(2,5,10$, and $30 \mathrm{~s})$ under $\mathrm{NH}_{3}$ atmosphere (200 $\mathrm{mL} / \mathrm{min}$ ) to produce samples denoted as NG-2, NG-5, NG-10, and NG-30, respectively.

\subsection{Characterization of catalysts}

Transmission electron microscopy (TEM) images were obtained with a field-emission transmission electron microscope (Tecnai G2 FEI). The elemental composition of the samples was determined by CHN elemental analysis (Elementar Vario MICRO). X-ray photoelectron spectroscopy (XPS, ESCALAB 250) was used to characterize the surface composition of the samples. Raman spectra were measured by micro-Raman analysis (JY HR800).

The ORR activity of the NG samples was evaluated in $\mathrm{KOH}$ solution $(0.1 \mathrm{~mol} / \mathrm{L})$ with a rotating ring-disk electrode (GC disk and Pt ring, Pine Instruments), coupled with a bipotentiostat (ACM). Pt foil and a Hg/HgO (1.0mol/L KOH solution) electrode were used as the counter and reference electrodes, respectively. The potentials presented in this study were referred to SHE. A mixture of catalyst ( $6 \mathrm{mg})$, ethanol $(1800 \mu \mathrm{L})$, and $5 \mathrm{wt} \%$ Nafion solution $(200 \mu \mathrm{L})$ was ultrasonically blended for $30 \mathrm{~min}$. Then, $40 \mu \mathrm{L}$ of this suspension (loading: $0.485 \mathrm{mg} / \mathrm{cm}^{2}$ ) was added dropwise onto the working electrode $\left(0.2475 \mathrm{~cm}^{2}\right)$. Linear sweep voltammetry (LSV) measurements were recorded by scanning the potential from 0.3 to $-0.7 \mathrm{~V}$ vs SHE at a scan rate of $5 \mathrm{mV} / \mathrm{s}$ using an electrode rotation rate of $1600 \mathrm{rpm}$. The ring potential was maintained at $0.7 \mathrm{~V}$ vs SHE to detect hydrogen peroxide.

\section{Results and discussion}

\subsection{Electrochemical characterization}

LSVs of graphene, NGs and 20\% $\mathrm{Pt} / \mathrm{C}$ in $\mathrm{KOH}$ solution $(0.1 \mathrm{~mol} / \mathrm{L})$ saturated with oxygen are shown in Fig. 1(a). For graphene, NG-2, NG-5, NG-10, NG-30 and 20\% Pt/C, the onset potentials for the ORR ( $\left.E_{\text {ORR }}\right)$ were $0.083,0.108,0.137,0.170$, 0.170 , and $0.211 \mathrm{~V}$, respectively. $\mathrm{N}$ doping had a marked effect on the ORR performance of graphene; EORR gradually increased
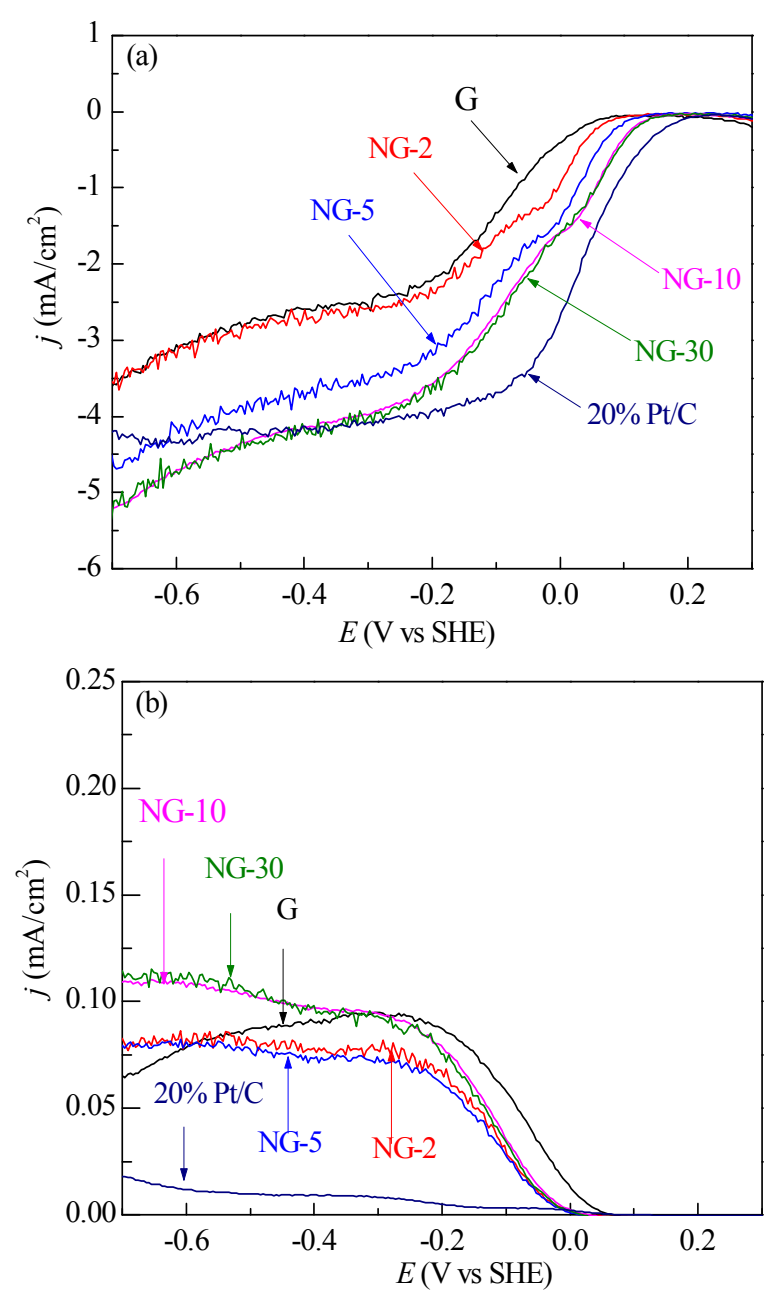

Fig. 1. (a) LSVs of graphene, NGs and commercial $20 \% \mathrm{Pt} / \mathrm{C}$, (b) the current density of the ring measured by RRDE for G, NGs and 20\% Pt/C.

with the microwave heating time. Little difference can be found for the ORR curves once the microwave time exceeded $10 \mathrm{~s}$.

The curves in Fig. 1(b) reveal that the numbers of electrons transferred per oxygen molecule $(n)$ at $-0.4 \mathrm{~V}$ for $\mathrm{G}$, NGs and $20 \% \mathrm{Pt} / \mathrm{C}$ were $2.88,3.03-3.30$, and 3.87 , respectively, according to the following equation [13]:

$$
n=4 I_{\mathrm{D}} /\left(I_{\mathrm{D}}+\left(I_{\mathrm{R}} / n\right)\right)
$$

The ring/disk current ratio $\left(I_{\mathrm{R}} / I_{\mathrm{D}}\right)$ was obtained from the data in Fig. 1(a) and (b). These results suggest that the reduction processes over NGs favored a four-electron over a two-electron pathway.

\subsection{TEM, Raman, elemental analysis, and XPS characterization}

TEM images of NG-10 are presented in Fig. 2. These TEM images revealed a voile-like structure (Fig. 2(a)), and the cross-sectional view of the edge of NG-10 showed that it contained only a few layers (typically less than 10) of graphene sheets (Fig. 2(b) and (c)). This suggests that the NG samples had a similar sheet structure to graphene and the layer number of the NGs was quite low.

Figure 3 shows Raman spectra measured for G and NG-10. There were two peaks in both the Raman spectra of $G$ and 


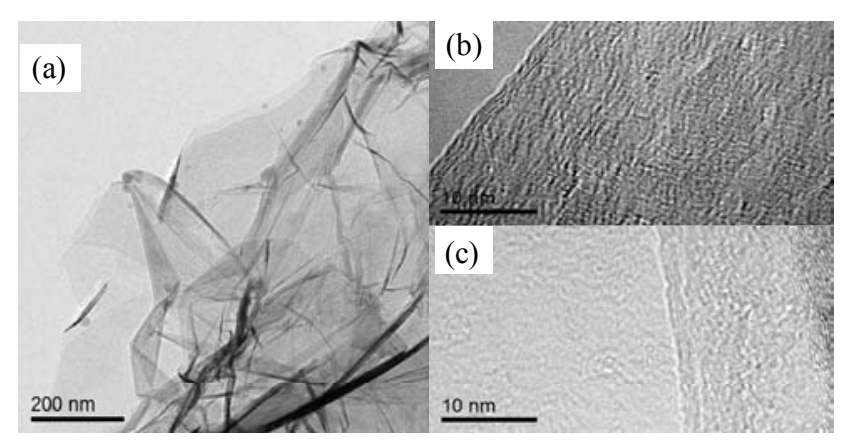

Fig. 2. (a) Low-magnification TEM image, and (b) and (c) high-magnification TEM images of NG-10.

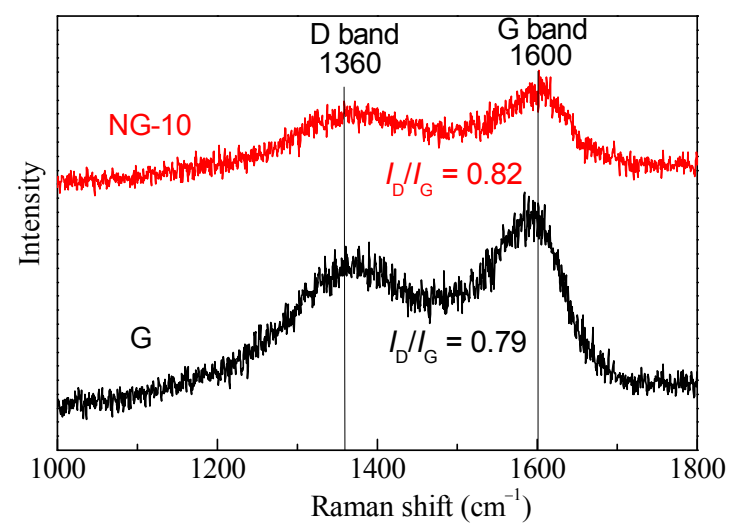

Fig. 3. Raman spectra of graphene and NG-10.

NG-10, which were attributed to the G band at around 1600 $\mathrm{cm}^{-1}$ and D band at $1360 \mathrm{~cm}^{-1}$, respectively [14]. It is known that the $\mathrm{D}$ band is related to disordered and defective carbon
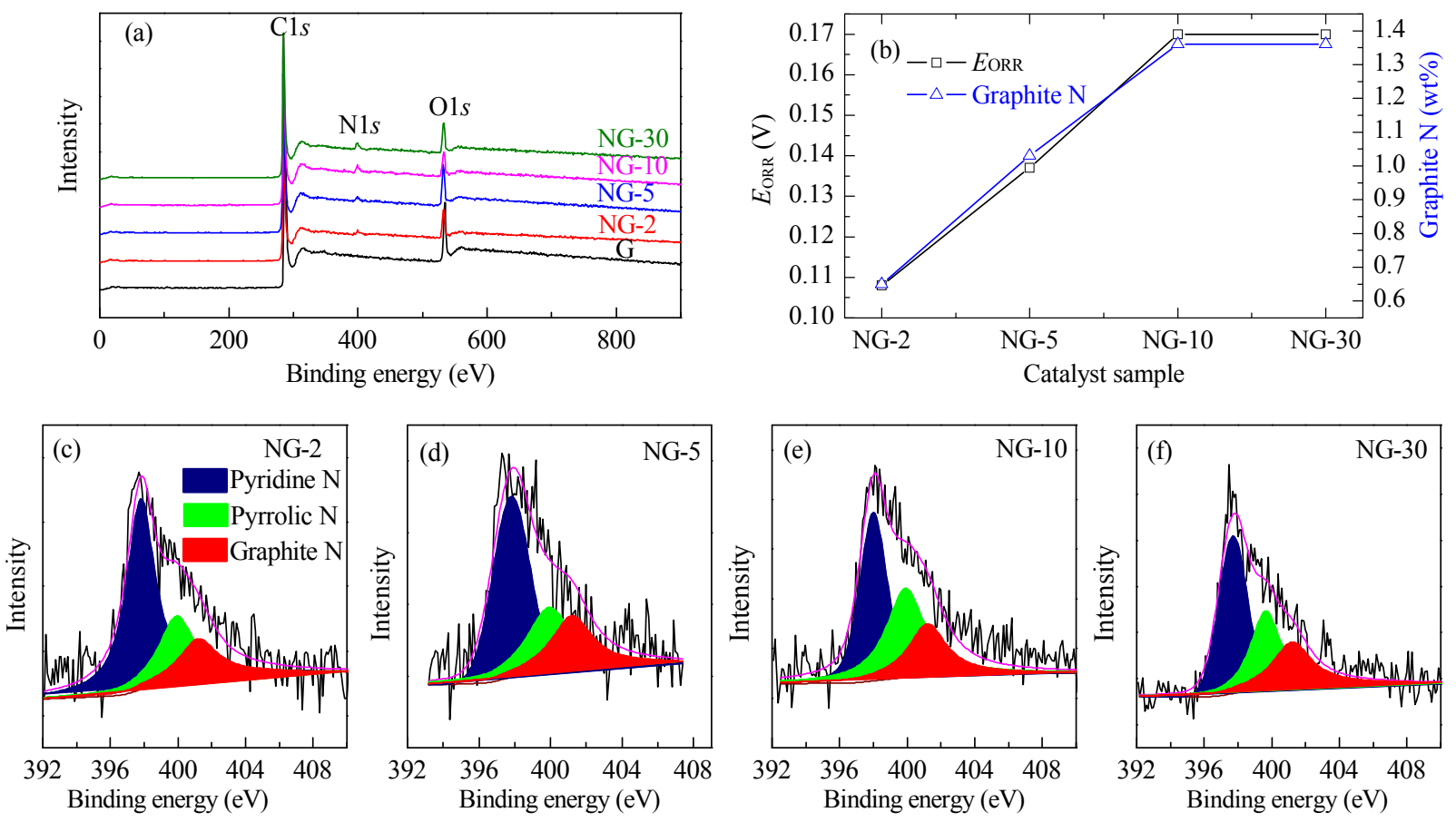

Table 1

Elemental composition of G, NGs and content of pyridinic, pyrrolic, and graphite $\mathrm{N}$.

\begin{tabular}{lccccccc}
\hline Sample & $\begin{array}{c}\mathrm{C} \\
\text { (wt\%) }\end{array}$ & $\begin{array}{c}\mathrm{O} \\
\text { (wt\%) }\end{array}$ & $\begin{array}{c}\mathrm{H} \\
(\mathrm{wt} \%)\end{array}$ & $\begin{array}{c}\mathrm{N} \\
\text { (wt\%) }\end{array}$ & $\begin{array}{c}\text { Pyridinic } \\
\mathrm{N}(\mathrm{wt} \%)\end{array}$ & $\begin{array}{c}\text { Pyrrolic } \\
\text { N (wt\%) }\end{array}$ & $\begin{array}{l}\text { Graphite } \\
\text { N (wt\%) }\end{array}$ \\
\hline $\mathrm{G}$ & 79.26 & 19.2 & 1.54 & 0 & & & \\
NG-2 & 86.85 & 7.73 & 1.37 & 4.05 & 2.4 & 1.0 & 0.7 \\
NG-5 & 87.94 & 6.1 & 1.36 & 4.6 & 2.2 & 1.4 & 1.0 \\
NG-10 & 88.58 & 4.99 & 1.36 & 5.07 & 2.2 & 1.5 & 1.4 \\
NG-30 & 88.02 & 5.16 & 1.35 & 5.47 & 2.4 & 1.7 & 1.4 \\
\hline
\end{tabular}

structure, while the G band corresponds to the well-ordered graphite structure [15]. The intensity ratio of the $D$ band to the G band $\left(I_{\mathrm{D}} / I_{\mathrm{G}}\right)$ increased from 0.79 for graphene to 0.82 for $\mathrm{NG}-10$, indicating that incorporation of heterogeneous $\mathrm{N}$ increased the number of structural defects.

The chemical composition of graphene and NGs was then characterized by elemental analysis, as illustrated in Table 1. Through microwave heating, the 0 content of graphene decreased from $19.2 \mathrm{wt} \%$ to around $5 \mathrm{wt} \%$, and the $\mathrm{N}$ content increased from 0 to over $5 \mathrm{wt} \%$. These changes were attributed to the addition of $\mathrm{NH}_{3}$ to replace residual oxygenic functional groups or $\mathrm{C}$ atoms of the graphene network [16] during microwave heating. The $\mathrm{N}$-doping process by microwave heating required only several seconds (2-30 s), which is much less time than thermal annealing (30 min) [4], and a considerable advantage compared with previous methods.

Successful N-doping was also proven by XPS analysis, as shown in Fig. 4(a). Peaks at about 284, 400, and $532.6 \mathrm{eV}$ could be assigned to the binding energy of $\mathrm{C} 1 \mathrm{~s}, \mathrm{~N} 1 \mathrm{~s}$, and $01 s$, respectively. To further investigate the bonding configurations of $\mathrm{N}$ atoms and their influence on ORR efficiency, high-resolution

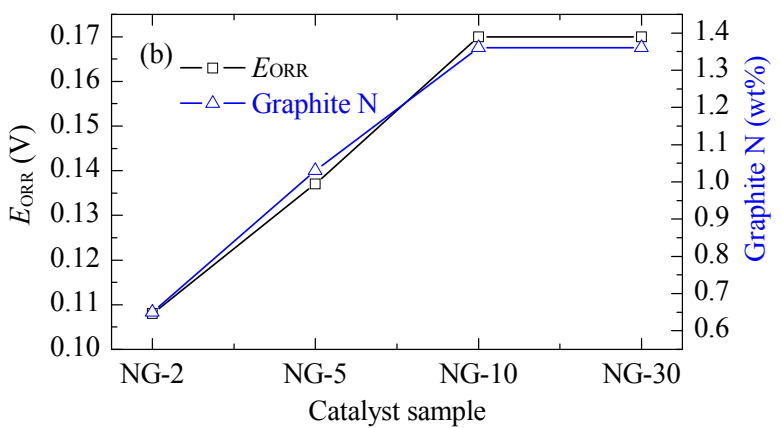

Fig. 4. (a) XPS spectra of G, NG-2, NG-5, NG-10 and NG-30; (b) $E_{\text {ORR }}$ and graphite N content of NG-2, NG-5, NG-10 and NG-30. High-resolution N-1s XPS of (c) NG-2,(d) NG-5, (e) NG-10, and(f) NG-30. 


\title{
Graphical Abstract
}

\author{
Chin. J. Catal., 2014, 35: 509-513 doi: 10.1016/S1872-2067(14)60016-4
}

\section{Rapid synthesis of nitrogen doped graphene by microwave heating for oxygen reduction reactions in alkaline electrolyte}

Zhongwei Wang, Bo Li, Yuchen Xin, Jianguo Liu*, Yingfang Yao, Zhigang Zou* Nanjing University

Nitrogen-doped graphene was rapidly synthesized via microwave heating by doping nitrogen atoms from ammonia molecules into graphene sheets.

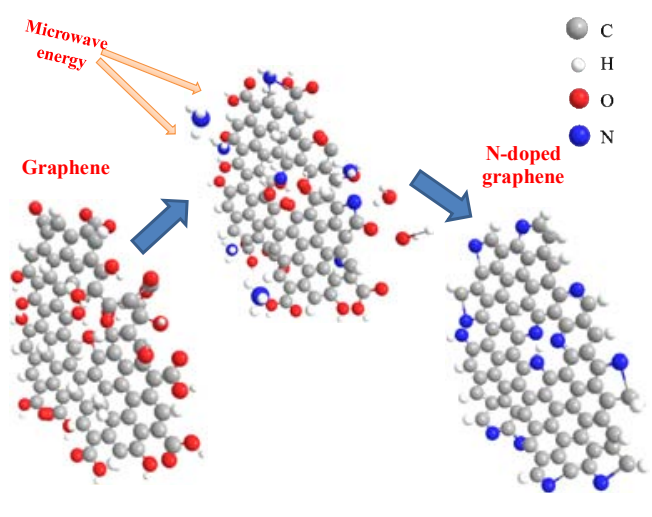

N $1 s$ XPS spectra of NGs were measured. As illustrated in Fig. 4(c)-(f), the peaks at around 397.9, 399.9, and $401.2 \mathrm{eV}$ could be attributed to pyridinic $\mathrm{N}$, pyrrolic $\mathrm{N}$ and graphite $\mathrm{N}$, respectively [17]. Table 1 presents the elemental composition of pyridinic $\mathrm{N}$, pyrrolic $\mathrm{N}$ and graphite $\mathrm{N}$ in the $\mathrm{NG}$ samples determined from XPS analysis. As shown in Fig. 4(b), as microwave heating time increased, the content of pyrrolic $\mathrm{N}$ and graphite $\mathrm{N}$ gradually increased, and that of pyridine $\mathrm{N}$ decreased. However, $E_{0 R R}$ showed a strong dependence on the content of graphite N. Both $E_{\text {ORR }}$ and graphite N content increased gradually with microwave time from 2 to $10 \mathrm{~s}$. However, NG-10 and NG-30 had almost same $E_{\mathrm{ORR}}$ and graphite $\mathrm{N}$ content. This suggests that graphite $\mathrm{N}$ was gradually doped into the graphene network during microwave heating, and became saturated when the microwave heating time exceeded $10 \mathrm{~s}$. It could be concluded that not all $\mathrm{N}$ doped into graphene has a marked effect on the ORR; that is, only the graphite $\mathrm{N}$ plays the main role in the ORR in alkaline solution.

\section{Conclusions}

This study reported the successful synthesis of N-doped graphene using a rapid, efficient microwave heating method under $\mathrm{NH}_{3}$ atmosphere. A N content of up to $5.47 \mathrm{wt} \%$ was obtained in just tens of seconds. As microwave heating time increased, the content of graphite $\mathrm{N}$ and $E_{\mathrm{ORR}}$ both increased. The doping of graphite $\mathrm{N}$ enhanced the activity of the catalysts in the ORR in alkaline solution.

\section{References}

[1] Wang Y J, Wilkinson D P, Zhang J J. Chem Rev, 2011, 111: 7625

[2] Liu Z L, Ling X Y, Guo B, Hong L, Lee J Y. J Power Sources, 2007, 167: 272

[3] Winter M, Brodd R J. Chem Rev, 2004, 104: 4245

[4] Lin Z Y, Song M K, Ding Y, Liu Y, Liu M L, Wong C P. Phys Chem Chem Phys, 2012, 14: 3381

[5] Yan X H, Zhang G R, Xu B Q. Chin J Catal (严祥辉, 张贵荣, 徐柏庆. 催化学报), 2013, 34: 1992

[6] Nagaiah T C, Kundu S, Bron M, Muhler M, Schuhmann W. Electrochem Commun, 2010, 12: 338

[7] Liu R L, Wu D Q, Feng X L, Mullen K. Angew Chem, Int Ed, 2010, 49: 2565

[8] Imran Jafri R, Rajalakshmi N, Ramaprabhu S. J Mater Chem, 2010, 20: 7114

[9] Kim Y A, Hayashi T, Kim J H, Endo M. J Energy Chem, 2013, 22: 183

[10] Qu L T, Liu Y, Baek J B, Dai L M. ACS Nano, 2010, 4: 1321

[11] Shao Y Y, Zhang S, Engelhard M H, Li G S, Shao G C, Wang Y, Liu J, Aksay I A, Lin Y H. J Mater Chem, 2010, 20: 7491

[12] Hummers W S Jr, Offeman R E. J Am Chem Soc, 1958, 80: 1339

[13] Schmidt T J, Paulus U A, Gasteiger H A, Behm R J. J Electroanal Chem, 2001, 508: 41

[14] Sheng Z H, Shao L, Chen J J, Bao W J, Wang F B, Xia X H. ACS Nano, 2011, 5: 4350

[15] Qian W, Cui X, Hao R, Hou Y L, Zhang Z Y. ACS Appl Mater Interfaces, 2011, 3: 2259

[16] Zhang L S, Liang X Q, Song W G, Wu Z Y. Phys Chem Chem Phys, 2010, 12: 12055

[17] Xin Y C, Liu J G, Jie X, Liu W M, Liu F Q, Yin Y, Gu J, Zou Z G. Electrochim Acta, 2012, 60: 354

\section{快速微波法制备掺氮石墨烯用于碱性氧还原电催化剂 \\ 汪忠伟 ${ }^{\mathrm{a}, \mathrm{b}}$ ，黎 波 ${ }^{\mathrm{a}, \mathrm{b}}$ ，辛宇尘 ${ }^{\mathrm{a}, \mathrm{b}}$ ，刘建国 ${ }^{\mathrm{a}, \mathrm{b}, *}$ ，姚颖方 ${ }^{\mathrm{a}, \mathrm{b}}$ ，邹志刚 ${ }^{\mathrm{a}, \mathrm{b}, \#}$ \\ a南京大学材料科学与工程系, 环境材料与再生能源研究中心, 固体微结构物理国家重点实验室, 江苏南京210093 \\ b南京大学昆山创新研究院, 江苏苏州2 15347}


烯用作碱性电解质条件下的氧还原电催化剂, 起始还原电势为 $0.17 \mathrm{~V}$ (vs SHE), 接近商用碳载铂催化剂的 $0.21 \mathrm{~V}$ (vs SHE). 采用透 射电子显微镜、拉曼光谱和X射线光电子能谱研究了掺氮石墨烯的形貌、结构和掺杂氮原子的键合方式. 结果发现, 掺氮石墨烯 的氧还原起始电位随着石墨氮原子含量的提高而上升, 说明石墨类型的氮含量是影响其氧还原催化活性的关键因素. 实验结果 表明, 微波法快速制备的掺氮石墨烯在碱性条件下表现出较高的氧还原催化活性, 具有作为碱性燃料电池阴极催化剂的潜力.

关键词: 燃料电池; 氧还原; 起始电位; 掺氮石墨烯; 微波法

收稿日期: 2013-11-28. 接受日期: 2013-12-27. 出版日期: 2014-04-20.

*通讯联系人. 电话: (025)83621219; 电子信箱: jianguoliu@nju.edu.cn

\#通讯联系人. 电话: (025)83686630; 电子信箱: zgzou@nju.edu.cn

基金来源：国家自然科学基金(21176111); 国家重点基础研究发展计划(973计划, 2013CB632404); 国家高技术研究发展计划(863 计划, 2011AA11A271); 江苏高校优势学科建设工程资助项目.

本文的英文电子版由Elsevier出版社在ScienceDirect上出版(http://www.sciencedirect.com/science/journal/18722067). 